\title{
Nigeria and the Organization of Islamic Cooperation: A Discourse in Identity, Faith and Development, 1969-2016
}

\author{
Babajimi Oladipo Faseke $\mathbb{D}$ \\ Department of History and International Studies, Redeemer's University, Ede 00176, Nigeria; \\ fasekeb@run.edu.ng
}

Received: 18 January 2019; Accepted: 26 February 2019; Published: 5 March 2019

\begin{abstract}
Nigeria is both a multi-ethnic and multi-religious society, with Islam and Christianity being the dominant religions. The Organisation of Islamic Cooperation (OIC) is therefore an institution that the Muslim segment of the country can readily identify with. However, there is the question of the secular posture of the country, which Christians within the polity use as an excuse to distance the country from an institution they perceive to be exclusively for Muslims. However, despite being an organization that emerged from Muslim solidarity, the OIC transcends faith to provide economic and political opportunities for member nations. The fact that Islam remains a rallying point within the OIC, however, made Nigeria's relationship with the organization tenuous for the most part. It is against this backdrop that the paper traces the origins and evolution of Nigeria's involvement with the OIC, identifying its cost and benefits. The essay argues that Nigeria will be the better for it if both the Christian and Muslim segments of the population embrace the OIC as a whole or are unanimous in discarding it. The divisive tendency that Nigeria's membership breeds, however, will be detrimental to the nation's unity and development.
\end{abstract}

Keywords: Nigeria; Organisation of Islamic Cooperation (OIC); foreign policy; secularity; economic aids

\section{Introduction}

Few foreign policy issues have raised as much dust as Nigeria's full membership of the Organisation of Islamic Cooperation (OIC) in 1986, a controversy that is yet to completely abate. The polemics can only be best understood in the regional, ethnic, and religious context of the polity. Nigeria is a densely populated country that has an almost equal representation of Moslems and Christians divided regionally, with the North being predominantly Islamic and the South mainly Christian. Such admixture has recurrently heightened political tensions. There is also a small fragment of the nation's population that practice indigenous religion. Due to this, the religious composition the constitution of the land is secular. Additionally, this particular fact partly explains the controversy the OIC issue generated; should a multi-religious society be involved in an organization that is steeply rooted in Islam? Despite the furor that the OIC palaver generated from certain quarters, the fact remains that Nigeria in 1986 became, and remains, the 46th member of the then Organisation of Islamic Conference (now Organisation of Islamic Cooperation). One important lesson learnt from this episode is that, in spite of the potency of public opinion in foreign policy conduct, ultimately, foreign policy decision-making in Nigeria lies in the hands of two institutions: The Ministry of Foreign Affairs (then External Affairs) and the Commander-in-Chief; but, as we will find out, the latter has the ultimate say and can therefore opt to isolate the former in implementing certain preferred courses of actions.

The OIC's case, however, does not need to be discussed in isolation from existing historical realities. Islam has been one of the main political and social forces in many parts of pre-colonial and post-colonial Africa, South as well as North of the Sahara (Kukah and Falola 1995). While the 
Muslim population in sub-Saharan Africa is more widely distributed and no state in this region regards itself as an Islamic State in the sense that countries in the Arab world do, black Africa may still be regarded as one of the major Islamic theatres of the world (Kokole 1984). The introduction and spread of Islam to Africa is well known. From 640 AD when Islam was introduced to Egypt it percolated subsequently to the south of the continent reaching West Africa and beyond by the end of that century. This was mostly through trade across the Sahara. The Usman dan Fodio jihad of 1804 was an emphatic consolidation of the religion in that region, particularly in the area that today constitutes the northern part of Nigeria-from where it spread less effectively southwards. The devoted Islam that dan Fodio had established had hardly survived half a century before colonial intrusion. The colonial period of course birthed secularism. It was only after political independence was achieved that African Muslims became more clearly aware of what the colonial 'interlude' had cost them; notably, the disruption of long nurtured institutions during the colonial period and the relative isolation of African Muslims from wider Islamic currents as well as the injection into their intellectual horizons of larger or smaller doses of western secular thought (Hunwick 1996, p. 232). This essay traces Nigeria's relationship with the OIC from its mere observer status to one of active membership. In-between, the debate that surrounded Nigeria's full membership is dispassionately captured as well as the ensuing attempts at resolution and conciliation. The paper further seeks to identify the benefits of the country's membership as well as the prospects of existing relationships with the OIC.

\section{Nigeria's Relationship with the OIC before 1986}

As earlier highlighted, the northern part of the country had for several years been Islamized before the advent of colonialism. As a consequence, after Nigeria's independence in 1960 the agenda of retracing their roots to the true worship of Islam and the fraternization with global coreligionist was rife among the northern elements. The government of the then Northern Region had in fact created links with Islamic regimes particularly in North Africa and the Middle East (Oded 1987). It was as a result of this connection that Sir Ahmadu Bello, the late Sardauna of Sokoto, became one of those charged with the responsibility of looking into the possibility of creating a permanent forum through which Islamic governments could interact frequently (Olukoshi 1990, p. 493). A great-great grandson of the founder of the largest Islamic empire in the Black World, Usman dan Fodio, Bello was committed to the legacy of his great-great grandfather (Enwerem 1995). For example, in his 16th May 1962 letter to the Secretary of the World Islamic Congress Ahmadu Bello, among other things, reminded his readers that, 'as you have known for two hundred years, my family have been associated with the spread of Islam and I only want to assure you [of] my fullest cooperation for continued effort to strengthen Islam day by day' (Paden 1986, p. 537). This is not to suggest, however, that the Sardauna was a religious fundamentalist; indeed he preached religious tolerance between Christians and Muslims in the North. In one of his Christmas messages, for example, he proclaimed that 'our differences may be great, but the things that unite us are stronger than the things that divide us ... ' (Bello 1959, p. 1) Such was the Premier's disposition that he was also able to get along well with his major Christian allies in politics. He had merely wanted to forge a closer relation between his region and the international Muslim community.

Bello, however, could not do much in this regard as he was assassinated shortly afterwards, during the January 1966 coup. The dream of solidarity with the Islamic world, however, did not evaporate with the demise of the Sardauna. After the burning of the al-Aqsa mosque and the consequent assembly of Muslim leaders in Rabat in 1969, a delegation of Nigerian Muslims, led by Abubakar Mahmoud Gumi, attended the conference with the prodding of the Sultan of Sokoto, Abubakar III. At the conference, Gumi pledged the support of the country's Muslim population towards the cause of solidarity that was to birth the OIC a couple of years later (Olukoshi 1990, p. 494). The air needed to be cleared, however, as to the capacity in which Gumi and his delegates attended the Rabat summit. Were they there in an individual capacity or did they represent the interest and views of the nation, Nigeria? It is important to note that during this period Nigeria was deeply involved in an ongoing 
civil war that was seen in some quarters as a religious conflict (Stremlau 1977). The war had pitted the minority Igbos in the southeast against the federal government of Nigeria, which was largely controlled by Northerners. In a bid to forestall an exacerbation of the conflict as well as not to give credence to the propaganda sold by the Biafrans that the civil war was in fact a religious conflict, Gen. Yakubu Gowon, the then Head of State, acted swiftly in making categorically clear that the presence of the Gumi delegation in Rabat was not a declaration of Nigeria's intention to become a member of an association of Islamic states since the polity was a secular state. Gowon went on to write an urgent note to King Hassan of Morocco, host of the 1969 summit, clearly stating that the Gumi delegation was a strictly private affair and did not represent the views of the Nigerian government in any way (Olukoshi 1990, p. 494). He, however, did not discourage such 'private' participation in later years. The direct implication of this is that when the OIC was fully constituted in 1971 Nigeria could not enroll as a member but remained relevant in the sense that delegates kept attending OIC meetings as mere 'observers'. Consequently, Nigeria was recognized by OIC countries as having an 'observer-status' within the organization, a status that remained unaltered by successive governments for the next fifteen years.

After the military ouster of the civilian government of Alhaji Shehu Shagari on December 31st, 1983 by Major-General Muhammadu Buhari things took a slightly different turn. Powerful Muslim groups in the northern and southwestern part of the country began a concerted and vigorous effort to make Nigeria become an active member in the OIC (ibid.). Some of these groups were commercial and industrial companies that had strong business ties with the Middle East. These groups began to lobby Buhari, who was already a devout Muslim that could readily relate with the importance of Nigeria joining such an organization (Ohadike 1992). Many Arab governments also mounted pressure on the new government to yield to this request, promising economic and financial assistance to the country should it become a full member of the organization. Such promises became particularly tempting in the face of a stalemate in the country's $\$ 2$ billion loan negotiations with the International Monetary Fund (IMF). The stalemate also led to the blockage of lines of credit to the country by Western banks and the withdrawal by Western export credit guarantee agencies of insurance cover on exports destined for Nigeria (Olukoshi 1990, p. 494). These conditions had naturally caused inflation and economic hardship in the country.

Despite all the allure of the pro-OIC lobby group, Buhari still managed to exercise caution and make recourse to the Ministry of External Affairs for advice. He sent a memorandum to the Ministry of External Affairs requesting advice on the issue. The ministry was also to provide a feedback as to the advantage and disadvantage of such an association. Ibrahim Gambari, the then Minister of External Affairs, in his reply to the memorandum, strongly counseled against the alteration of Nigeria's observer status in the OIC because of her secular posture, as provided in the 1979 constitution. He also noted that it was an issue that could divide the country along religious lines (Gambari 1989). Buhari's response to this counsel is not quite clear, but from evidences available he did not appear to be in consonance with the minister's reply. In fact, there were allegations from certain quarters that Buhari had set in motion the process that will guarantee Nigeria's full membership in OIC and that his deputy, Tunde Idiagbon, had traveled to Saudi Arabia in mid-1985 to facilitate the process (Olukoshi 1990, p. 494). The full intentions of the Buhari administration concerning Nigeria's full membership in the OIC never materialized as he was ousted by Gen. Ibrahim Babangida coup of 27 August 1985.

\section{Nigeria's Full Membership of the OIC}

The OIC saga did not end with Buhari's ouster. Indeed, the new administration of General Babangida continued to be lobbied by pro-OIC groups. Their argument remained ever persuasive in the face of incessant economic problems and the hard stance of Western financial institutions like the IMF in issuing assistance. This warranted Nigeria seeking potent alternatives to these Western financiers in kick-starting the country's economic recovery. Consequently, like what Buhari had done, Gen. Babangida sought the advice of the Ministry of External Affairs on the implications of Nigeria's 
full membership in the organization. Like his predecessor, the then Minister of External Affairs, Professor Bolaji Akinyemi counseled against such a move, citing similar reasons to those of Professor Gambari (ibid.). The Babangida administration, however, was not contented with the ministry's report and preceded to set in motion plans of enrolling Nigeria into the OIC on a full term basis. In the interim, the OIC secretariat in Jeddah sent an invitation to Nigeria in December 1985 to attend the organisation's ministerial meeting that was scheduled for 6 to 10 January, in Fez, Morocco. As was the practice, the Ministry of External Affairs asked the Nigerian Ambassador in Morocco to make arrangements to 'observe' the proceedings (Ibid.). The ministry had apparently been ignorant of the government's intentions. On 1 January 1986, however, Babangida arranged a Nigerian delegation to attend the ministerial meeting in Fez. The delegation contained prominent personalities that held important offices in government; and they were all-naturally enough-Muslims. It was led by Rilwanu Lukman (the then Minister of Mines, Power and Steel) and included Abubakar Alhaji (the then Permanent Secretary in the Ministry of National Planning), Abdukadir Ahmed (the then Governor of the Central Bank), Ibrahim Dasuki (the then Secretary General of the Supreme Council for Islamic Affairs), and Abubakar Mahmoud Gumi, the former Grand Khadi of Northern Nigeria. The delegation arrived in Fez on 8 January and participated in the meeting for the first time the next day, after the Nigerian Ambassador to Morocco, who had been present from inception and had been oblivious of the impending arrival of the delegates, had registered his presence as a mere observer (Olukoshi 1990, p. 496).

It was during the first participation of the delegates at the meeting, on 9 January, that Nigeria's formal application for full membership into the OIC was made. The hierarchy of the organization was so profoundly delighted with this submission that they decided to waive some procedures that were statutorily required for admittance into the OIC. Rather than waiting a full probationary year before Nigeria's admission is communicated to her, the organizers of the meeting only requested that its application be sponsored by existing members: a task that countries like Syria, Sierra Leone, Pakistan and Senegal happily fulfilled. When it was time for the conference chairperson to make his remark, he spoke in glowing terms of Nigeria and lauded her decision to become full members of the association. According to him, 'your seat has always been reserved and we hope you will apply your zeal for the achievement of the aims and objectives of the OIC' (ibid). The leader of the Nigerian delegates, Rilwanu Lukman, thanked the chairperson and other members and pledged the country's support to the cause of the organisation. This exchange, therefore, marked the official entry of Nigeria into the OIC as full members. Years after leaving office, Akinyemi maintains that 'Babangida must have known that the Christians would kick against the decision. This is why all previous governments had worked out that compromise of our being an observer rather than a full member' (Akinyemi 2018). He also notes that it was from then on that religion became a tendentious issue in Nigerian politics (ibid.).

\section{The Domestic Front: Actions and Reactions}

It was the national French news agency that broke the news to Nigerians that Nigeria had somewhat clandestinely been admitted as the forty-sixth member of the OIC (Falola 1998, p. 94). Most Nigerians had hitherto been unaware of the organization and the news of Nigeria's membership almost went unnoticed had it not been the persistence of certain prominent clerics, notably Archbishop Okogie of Lagos, as well as the news media (Kukah 1993, p. 230). Clerics as well as Christian journalists made frantic moves to confirm from government if and why Nigeria had truly become a member of the organization. Christians became even more restive when it was discovered that top government officials like the Chief of General Staff, the Foreign Minister, Minister of Internal Affairs and the Minister of Information, who were Christians, were just as equally bemused and ignorant of the decision as the general public. For example, the second in command to the Head of State, Ebitu Ukiwe, publicly declared that he had been unaware of such a big policy decision. Indeed, many Nigerian Christians believed that it was this public utterance that led to his removal from office by Babangida 
(Falola 1998, p. 95). In many ways, this entire episode played into the hands of those Christians that had all along held the view that 'there was a secret plan for the Islamization of Nigeria' (Ibid).

The immediate fallout of Nigeria's full membership of the OIC was that it deeply divided the country along religious lines. Both Christians and Muslims anchored their opposition and support on the interpretation of the secular status of the country. Christians demanded an immediate withdrawal from the organization because the 1979 constitution clearly makes the nation a secular one. Muslims, on the other hand, argued that the secular posture of the country had not been violated in any respect since the country was not adopting Islam as a state religion. Championing the Christian cause was the Christian Association of Nigeria (CAN), which was led by Archbishop Okogie. Its position was Nigeria's total and unconditional withdrawal from the OIC. According to Okogie, 'if it were a section of the Islamic Community that joined, there is no problem, but for Nigeria as a country, we hold the President responsible for this. The President alone does not make up Nigeria' (Okojie 1986, pp. 12-14). In response, the umbrella body of the Muslim community, Jama'atu Nasir Islam (JNI), argued that the call for withdrawal was part of the 'insensitivity of Christians towards matters that concern Muslims ... if Nigeria withdraws from the OIC, it will have to withdraw diplomatic relations with the Vatican' (Jama'atu Nasir Islam 1986).

Other debaters who were not as extreme in their views as the CAN and JNI tried to defend their positions in more concrete terms. For example, those that favoured Nigeria's association with the OIC argued that Christians had exaggerated the negative implications of the OIC, pointing out that some Christian heads of state like Uganda, Rwanda, Gabon, Kenya, Cameroun, Sierra Leone and Benin Republic were members of the OIC; and therefore, the organization was not essentially a religious one, but something in the mold of the United Nations (Lawal 2018). This group of people also emphasized the positive financial implications like monetary and technical assistance as well as the low-interest loans, which the Islamic Development Bank (IDB) provided.

Anti-OIC lobbyist met the Muslim responses point for point. They made the case that, unlike Nigeria, countries with significant Christian population that joined OIC did so because they were troubled nations whose leaders were seeking quick fixes to their problems. This group of persons was equally unimpressed with the so-called economic allure of the organization. They argued that OIC member countries that had obtained financial support from the organization were not faring better than Nigeria. They added that since (at that time) Nigeria was the seventh richest of the forty-six members, Nigeria was likely to sink more money into the organization than it would recoup from it because it would be expected to carry a large share of the financial burden of the organization. In this regard, therefore, the group concluded that the Islamic Development Bank was not a viable substitute to the IMF. Instead, it was necessary the country looked inwards (Falola 1998, p. 98). In response to the comparison with Nigeria's relations with the Vatican, a technocrat pointed out that 'the diplomatic relations with the Vatican have no religious basis, and will not have unless we enter into special concordat with the church. Such special relations are enjoyed by a limited number of countries whose state religion is Roman Catholicism (Jolaoso 1986, p. 9).

\section{Resolving the Impasse}

Seeing how heated the country was on the issue, Gen. Babangida acted swiftly by creating a committee to assess the implication of Nigeria's membership of the OIC as well as releasing to the public the official rationale for joining the organization. His reasons for admittance were anchored on both economic and political considerations. The Babangida administration sought to salvage the country's economy through the accessibility of interest-free loans that the IDB, one of the associated institutions of the OIC, provided. As at December 1979, the IDB had approved $\$ 943.32$ million in interest-free loans that covered 114 projects in 30 member countries of the OIC (Piscatori 2000, p. 78). In a political sense, the head of state also considered the organization as one that will allow Nigeria to rally against racism and colonialism. He cited as evidence the fact that apart from Turkey, all OIC members also belonged to the Non-Aligned Movement. Additionally, many of the nation's neighbors 
that were members of the Oraganisation of African Union OAU were also members of the OIC. Therefore, the organization, he argued, was a platform for members of the Third World countries to seek cooperation between themselves. The altruistic value of Babangida's actions has, however, been questioned. While believing the aforementioned to have influenced the decision of the head of state in enrolling the country into the OIC, Falola (1998) also believed Babangida to have acted in this regard in order to win over the powerful Muslim constituency for his own good. According to the scholar, he had not been regarded as a good Muslim by many members of this community. Therefore, joining such an organization will most probably better their image of him (ibid., p. 95).

On 28 January 1986, the committee saddled with the responsibility of examining the implications of Nigeria's membership in the OIC was set up and was inaugurated on the 3 February 1986. It was at this inaugural session that the head of state publicly revealed his aforementioned stance on Nigeria's involvement with the organization. The twenty-man committee was headed by the then Minister of Interior, Lt. Col. John Shagaya, a Christian from the north-central region of the country. Other ministers that made up the committee were Prof. Bolaji Akinyemi (External Affairs), Lt. Col. Anthony Ukpo (Information and Culture), and Prof. Jubril Aminu (Education). Other eminent members were Alhaji Ibrahim Dasuki, Dr. Joseph Adegbite, Archbishop Anthony Okogie, Alexander Bada, and Justice Ahmed Lemo. Others included Alhaji Iman Isiaka Idris, Alhaji Suleiman Onyeama, Prof. Nurudeen Alao, Alhaji Babatunde Jose, Bishop Rogers Uwadi, Rev. S.T Ola Akande, Elder G.A.M Otubu, Archbishop Stephen Ezeanya, Bishop Abiodun Adetiloye, Mr. Justice Bashir Sambo, and Prof. Dandatti Abdul-Kadir. If the composition was gender insensitive, it certainly had a religious balance with both Muslims and Christians having ten representatives each.

By 21 March, the committee had submitted their report to Gen. Babangida's second-in-command, Ebitu Ukiwe. While members of the committee fronted a harmonious relationship between themselves, it was evident that this was a mere charade. The report of the committee was not unanimous as both sides held on to two diametrically opposed positions. For this reason, the Federal Government never published a white paper stating the committee's position on whether or not to withdraw as full members of the OIC. Instead, the most tangible outcome of the panel was the recommendation of the need for inter-religious cooperation and the necessity to create a body to foster this. In presenting his report, Lt Col. Shagaya commented that,

our terms of reference require us to set out the implications of Nigeria's full membership of the OIC. This we have done to the best of our ability. We have also noted in our report the hopes and fears as well as the suspicions and grievances of our fellow countrymen and women on religious matters. But we have against this stated our conviction that such differences as spring (sic) from these feelings will be adequately taken care of in the suggested, permanent consultative forum as time goes on. (Shagaya 1986, p. 1)

Following the presentation, Gen. Babangida decided to make the consultative body permanent and christened it 'the Advisory Council on Religious Affairs' (ACRA). While the membership of the new body was slightly increased, it was largely constituted of the same participants of the original panel. The choice of members of ACRA also remained the prerogative of the head of state.

The fact that the Shagaya committee ended in a deadlock, it did not come as a huge surprise. Apart from the fact that most of the members were deeply religious and uncompromising in their faith, they also resorted to forming sub-committees among their co-adherents through which they sought advice on what position to take during panel deliberations. For example the president of the Christian Council of Nigeria (CCN), Dr. Joseph Adegbite, who also served as a member of the panel, facilitated the formation of a sub-committee. The sub-committee was set up on 15 February 1986 by a meeting of church leaders at the Anglican Bishop's court in Marina and was charged with the responsibility of drafting the CCN's stand on the OIC affair. Such a move was perhaps in response to a similar action taken by the Sultan of Sokoto on the same day the Shagaya panel was inaugurated. The Sultan had announced the formation of a 12-man committee of his that was to advise him on the OIC matter. This is significant because there were a number of JNI members in the Shagaya panel who-naturally 
enough-owed the Sultan allegiance. The implication of the creation of these sub-committees was the tendency to result in a hardline stance on the OIC issue during committee meetings, with members of both religions being determined to be absolute gainers. In fact, 'ACRA was never going to lead to Nigeria withdrawing from the OIC; it was just meant to dampen the tension' (Akinyemi 2018).

The Babangida administration in its wisdom calculated that rather than affirm Nigeria's membership or announce its withdrawal, it would be mute on the matter and allow sleeping dogs lie. Apart from the initial rancor and occasional agitation from the Christian segment of the Nigerian population in the ensuing months, the strategy appeared to work. The fervor with which the matter was taken seemed to wane by the following year. Throughout the Babangida administration, which ended in 1993, it was only during global events that affected the OIC — and Nigeria by extension - that the debate was revisited. One example was the publication of the highly controversial book of Salman Rushdie, The Satanic Verses, which was considered an apostasy by the larger percentage of Muslims globally (Haynes 2012). The matter was tabled at the 1989 OIC meeting and it threatened to divide the organization itself. While Iran under its supreme leader, Ayatollah Khomeini, advocated for Rushdie's death and total boycott of the West that allowed the publication of such a book, Saudi Arabian prince, Saud Al-Faisal reaffirmed that the OIC 'was not an assembly of jurisprudence', and therefore maintained a moderate position that, while the book and the publishers be banned from all OIC member countries, the call for Rushdie's head be dropped. Ultimately, it was Saudi Arabia's position that prevailed. But, tellingly, the Supreme Council for Islamic Affairs that represented Nigeria at the meeting decided to vote for Ayatollah's position on the issue (Ofeimun 1989, p. 9). The matter again raised dusts, making some question Nigeria's agenda with the OIC, particularly because of Iran's influence on the organization (ibid.).

\section{Post-Babangida Era and Nigeria's OIC Status, 1993-2016}

By the time Babangida left the seat of power on 27 August 1993, the status of Nigeria's membership had been hazy. While, in a bid to satisfy Muslims, Nigeria had not officially withdrawn from the organization, it refused to play an active role or publicize its participation in the OIC so as to placate the Christians. This tightrope position was maintained in the country for at least the following five years. Indeed, during that time there were more pressing issues that concerned Nigerians. First, there was the controversial annulment by Gen. Babangida of the 12 June 1993 election that Moshood Abiola had convincingly won. The second issue was the consequent installation of Chief Ernest Shonekan as 'Interim President' after the head of state decided to resign in August. The twin events generated commotion and crisis that cumulated in the ouster of the interim president by Gen. Sanni Abacha in a military coup of November 27 1993. Abacha was infamously known for stifling freedom of speech and ruthlessly punishing dissent during his regime. Though the new head of state maintained the 'let-sleeping-dogs-lie' policy of the Babangida era, the fear of being ruthlessly repressed probably precluded further Christian activism on the OIC issue.

However, shortly before Abacha's death on 8 June 1998, the OIC debate resurfaced. Having just returned from an OIC meeting in Iran, the Sultan of Sokoto in April announced to members of the JNI the resuscitation of Nigeria's full membership status in the OIC (Dickson 1998, pp. 1-2). Like had been the case in the 1980s, the Sultan tried to assure Nigerian Christians that Nigeria's membership was not for ulterior motives but for economic benefits; and that membership should not generate any controversy as it had done when similar news was announced in 1986. As can be imagined, the pleas of the Sultan fell on deaf ears as almost immediately after the news some Christian groups started agitation against such a move. One of such groups was the 'Christian Ethics in Nigeria' (COCEN), Akure branch. In a communiqué released to the public, the group claimed that,

The development is capable of engineering a religious war and no nation has survived a religious war and remained the same thereafter. We warned in clear terms that all Nigerian Christians within and outside Nigeria shall be mobilized by COCEN to resist at any cost, Nigeria's membership of OIC in any colouration. (Christian Ethics in Nigeria 1998, p. 4) 
It is difficult to predict what Abacha would have done under the new circumstance since he passed on only about a month later. The succeeding head of state, Gen. Abdulsalami Abubakar was far more liberal than his predecessor and guided the country through a democratic transition on 29 May 1999. Many had anticipated that the new democratically elected president, Olusegun Obasanjo would end the OIC saga in favor of Christians since he was the first substantive Christian leader Nigeria had witnessed in twenty years. They were, however, disappointed as the new president did nothing to alter the existing status quo. In fact, he had been the one that paid the outstanding membership fees owed to the OIC that precluded the country from reaping rewards of membership (Akhaine 2008). Indeed, his foreign minister, Alhaji Sule Lamido, was a devoted Muslim, who used his office to facilitate Nigeria's involvement with OIC. In fact, no administration since Nigeria's return to democracy in 1999 has tampered with its OIC membership status; not even President Goodluck Jonathan, who was not only a Christian, but also a native of a region that is predominantly Christian. To be sure, when on 11 April 2008, the Christian Association of Nigeria (CAN) demanded to know whether Nigeria was still a full member of the OIC or not, the then Minister of State for Foreign Affairs, Alhaji Tijani Kaura, answered in the affirmative only three days later (Kaura 2008, p.13). Up till 2012, there were pockets of agitation against Nigeria's membership of OIC from Christian clerics in particular. But, in general, such resistance has waned and reality seems to have set in that Nigeria's full membership status is permanent for the foreseeable future. It is worth noting that one of the reasons for the relative calm on the OIC matter during Nigeria's democratic dispensation is that Nigeria's return to civil rule roughly corresponds to the time the OIC underwent extensive restructuring. The reforms, which took place in 2001 entailed, among other things, a revised charter set out to promote human rights that was no longer defined solely on Islamic terms. Such a revision effectively replaced the 'Cairo Declaration on Human Rights in Islam' with the 'Universal Declaration of Human Rights and international law' that was now endorsed by member nations. Such a gesture led to the belief that OIC was now more of a modern political institution rather than an institution based on Islamic solidarity alone. According to an OIC technocrat, 'such a change was to keep in touch with the dynamic changes in the world' (Lawal 2018).

\section{Nigeria's Membership of the OIC: to What End?}

Having been established that Nigeria is a full and active member of the OIC, the question follows: what has the nation gained? Since economic benefits were said to be the main reason for Nigeria's involvement in the group, it is only natural we channel our assessment along this parameter. In attempting an answer, it is first important to note that, since its inception, the organization has had tangible economic impact on some of its member states. This has come through its specialized and affiliated institutions like the Islamic Development Bank (IDB), Islamic, Educational, Scientific and Cultural Organisation (ISESCO), Standing Committee for Economic and Financial Cooperation (COMCEC), among others. Indeed, one of the earliest notable examples of the OIC influence is the raising of $\$ 10,000,000$ among members in 1988 to help Palestinians, who were 'victims of Israeli oppression in the occupied West Bank and Gaza area' (Al-Gabid 1993). Also, towards the end of the year 1989, the OIC set up a 'food reserve scheme', which was to help member countries cope with emergency food shortages (ibid.). Under such plan, each participating nation would pledge one percent of its consumption of staple food to the OIC reserve to be kept in the country ready to be shipped anytime another member required it. Another example is the cancellation of the official debt owed by less developed countries (LDCs) that were members of the OIC by Saudi Arabia, the wealthiest nation within the organization. The most important benefit to members, however, can be attributed to the Islamic Development Bank (IDB), which is a subsidiary institution of the OIC. Apart from the several millions spent in the 1990s on Africa, an "IDB Cooperation Framework with Africa" initiative was further funded with a commitment of $\$ 2$ bn for least-developed member countries in Africa over a five-year period (2003-2007) (COMCEC 2017). This was extended through the Special Programme for the Development of Africa (SPDA), which is a $\$ 12$ bn investment programme in African countries for the period 2008-2013 (ibid.). 
As a result of the tightrope Nigeria maintained in pleasing both Muslim and Christian constituencies in the country between 1986 and 2000 by being inactive in the organization, the tangible benefits of the nation during that time are at best obscure. The new millennium, however, seems to have ushered a new dawn. Having endorsed Nigeria's membership of the OIC, President Olusegun Obasanjo effectively enrolled Nigeria into the IDB in 2005 with the purchase of 0.03 percent of the overall capital of the bank (Ezeanokwasa 2007). This capital subscription was increased to 7.69 percent in June 2010, making the country become one of the nine permanent members of the Board of Executive Directors (ibid.). This also made Nigeria the fourth-largest equity subscriber to the IDB with 1384 million Islamic dinars (ID).

In reward for such commitment, Nigeria has been able to attract some economic benefits. For instance, in pursuance of the implementation of the transformation agenda of the government of Nigeria and IDB's Strategic Plan, an indicative 3-year Country Programming Framework (2012-2015) was formulated. Under the programme, the bank and its affiliates provided financing envelop of \$2billion for the implementation of projects in the priority areas of agriculture, energy, transport, water supply and sanitation, education, and health. In fact, as of 2012 alone, a budget of about $\$ 700$ million was considered by the bank for Nigeria. This included 8 approved projects to the tune of \$200 million and trade financing for \$205 million granted to prominent companies and banks in the country (ibid.). This is not to mention the $\$ 30$ million for the 'Food Security Program' that covered Gombe and Yobe States. In addition, there was the provision of facilities for the construction of 4 Model Science Secondary schools and 300-bed specialist hospitals in Kaduna State. Integrated Rural Development Project and Bilingual Education Program were also provided in at least 11 other states (ibid). The IDB, in addition, sponsored study visits of 13 Nigerian irrigation experts from seven states and Federal Ministries of Agriculture and Water Resources for two weeks to successfully implement/manage small-scale irrigation projects in Indonesia in April 2012 under the 'Reverse Linkage Program.' The aim of the visit was to enable the delegation observe best practices, provide short term training for trainers and fill the skill gap to train operators and training institutions in the operations and maintenance of small scale irrigation infrastructures in Nigeria. The ultimate goal of such technical assistance was to help Nigerian small scale farmers improve their agricultural production through adoption of best farming practices that could result in less dependence on rain-fed agriculture, and enhancement of productivity.

Another significant event occurred in the year 2012. In order to foster cooperation with Nigeria and enhance the bank's country presence and improve client's responsiveness, there was the establishment of a Group Gateway Office in Nigeria. States desirous of IDB financing for projects in the category of Medium Term Priorities were to apply through the IDB Governor for Nigeria (also statutorily Nigeria's Minister of State for Finance) along with a detailed feasibility study and the State's Assembly Resolution authorizing such borrowing (ibid.). In a case where the feasibility was not available, the Bank could consider financing it upon the request of the country. Private sector application for financial support was also accommodated through this medium, requiring only a direct application (accompanied with a comprehensive project report) to the IDB Governor. Adamawa, Gombe, Kaduna, Kano, Kwara, Nasarawa, Niger, Osun, and Yobe are states that have benefited from these interest-free loans. Most southern governors are yet to enjoy such benefits, perhaps so as not to offend the significant Christian population in their constituencies.

In January of 2016 the IDB came up with the 'Bilingual Education Scheme.' The program aimed at educating the jobless youths in both Islamic and Western education. This is significant because the bulk of these idle youths constitute the recruiting pool of the Boko Haram BH (Faseke 2013). This was done in a bid to reconstruct northern Nigeria after the $\mathrm{BH}$ onslaught had ravaged the region between 2009 and 2016. This arrangement was made when the IDB's President, Ahmad Ali, on 31 January 2016, received a high level delegation of 5 governors from the Northern Nigerian States Governors Forum, NSGF. The delegation was led by the Governor of Borno State, Kashim Shettima, and included Abdullahi Ganduje of Kano State, Nasir El-Rufa'i of Kaduna State, Umar Al-Makura of 
Nassarawa State and Muhammad Abubakar of Jigawa State. Mr. Ali committed himself and the IDB to " ... work(ing) together to come up with a comprehensive and constructive plan to support northern Nigeria". According to him "We will start with education, particularly bilingual education, and other areas such as job creation" (Tukur 2016). Within the next few weeks the IDB provided \$98m for the Bilingual Education Program in Adamawa, Gombe, Kaduna, Kano, Kwara, Nasarawa, Niger, Osun, and Yobe, and also promised to support similar projects in other states of the country (Adetayo 2016). This development was very welcomed by President Muhammadu Buhari, who a few weeks later also welcomed an offer by the IDB to organize a financing round-table in Abuja to mobilize more funds for investment and development of infrastructure in Nigeria (ibid.).

The essay has not by any means exhausted all the benefits Nigeria profited from the organization as this is not the primary and sole focus of the work. It goes without saying, however, that there have indeed been developmental gains from Nigeria's involvement with the OIC through its separate agencies. For example, the fear that Nigeria will expend more money on the organization than the rewards it will gain has proved to be unfounded as member nations pay the same amount of annual subscription and take advantage of the full benefits accruing to them by virtue of being members (Shinkaiye 2018). One of the strongest critics of Nigeria's membership of the OIC, Bolaji Akinyemi, agrees that there were definitely economic gains from the organization. However, he also cautions that 'one has to keep in mind that at times economic gains may not be sufficient to counter strategic problems that you get yourself into by certain decisions' (Akinyemi 2018). He also opined that, though there are Christian countries in the OIC, these countries do not have the sort of religious tensions that existed in Nigeria.

\section{Conclusions}

The OIC matter is another issue that highlights the divisive tendency of religion, particularly in a multi-ethnic and multi-religious country like Nigeria. To be sure, Nigeria's involvement with the organization is just one of a number of issues that have caused cleavages between Christians and Muslims in the polity. Perhaps, what makes this particular case more sensitive is the secrecy associated with it. This appears to have brewed suspicions and speculations, particularly among the Christian segment of the population. Foreign policy decision-making has indeed generally been a secretive bureaucratic affair that is restricted to the esoteric world of diplomats and politicians in power. Usually, when routine decisions are made, the secrecy involved-often justified on various grounds-does not raise public suspicion. However, the religious sensitivity in the OIC issue in many ways made people rethink the lack of openness in the country's foreign policy. Apart from the fact that openness could have prevented the heated passion with which the matter was received, Nigeria perhaps would have by now evaluated the cost and benefits of membership or non-membership more objectively and effectively too.

However, one must not fail to mention the place of Nigeria's membership of the OIC within the context of the country's secular posture. Indeed, the spirit of both the 1979 and 1999 constitutions brand Nigeria a secular nation, but what that exactly means is subject to interpretation. If, as we have identified, there are material gains in being members of the organization, then such membership should be embraced and the nation should seize every opportunity membership provides. On the other hand, the altruism of the organization also has to be tested. Are the material gains provided to member-nations strictly a means of bettering them economically or there is the agenda of promoting Islam and, perhaps, elevating the Muslim constituency over their Christian and indigenous religion counterparts in these nations? The fact that most states within the Nigerian polity that have accessed loans from the IDB are states with predominantly Muslim populations in the north raises concerns. The notable exception is Osun State, which, at the time of access, was governed by a very fervent Muslim, Rauf Aregbesola. It is important to point out, however, that it is unclear whether other states willfully decided against exploring the IDB option or there is an institutional lapse within the organization itself that precludes such states from partaking. The point to be made is that, in the 
interest of Nigeria's nationhood, the OIC should either be embraced by all or be rejected by every; and the parameter for deciding which way to go should be the altruism of the organization. A situation where it is embraced by a particular constituency and rejected by the other is dangerous for the nation's continued existence.

Funding: This research received no external funding

Conflicts of Interest: The author declares no conflict of interest.

\section{References}

Adetayo, Olalekan. 2016. Islamic Bank's Offer to Nigeria Excites Buhari. Punch. February 25. Available online: http:/ / www.punchng.com/islamic-bank-offer-to-nigeria-excites-buhari/ (accessed on 24 March 2016).

Akhaine, Saxone. 2008. Northern CAN Tasks Obasanjo on OIC. The Guardian. April 3. Available online: http:/ / odili.net/news/source/2008/apr/3/23.html (accessed on 27 February 2019).

Akinyemi, Bolaji. 2018. (Nigerian Minister of External Affairs, 1985-1987). Interview with Babajimi Faseke. Lagos, Nigeria, August 17.

Al-Gabid, Hamid. 1993. The Organisation of Islamic Conference (OIC) and the development of Africa. In Islam in Africa. Proceedings of the Islam in Africa Conference. Edited by Nura Alkali, Adamu Adamu, Awwal Yadudu, Rashid Moten and Haruna Salihi. Ibadan: Spectrum Books, St. Helier and Channel Islands: Safari Books, pp. 305-21.

Bello, Ahmadu. 1959. Christmas Message. Nigerian Citizen, December 30, 1.

Christian Ethics in Nigeria. 1998. Withdraw Nigeria from OIC to avert Religious War. Vanguard, May 8, 4.

COMCEC. 2017. Report on the Special Program for the Development of Africa (SPDA). Available online: http: //www.comcec.org/en/wp-content/uploads/2017/04/33-FC-IDB-SPDA.pdf (accessed on 10 December 2018).

Dickson, Andrew. 1998. Nigeria to join Islamic Bank. The Guardian, 1-2.

Enwerem, Iheanyi. 1995. A Dangerous Awakening: The Politicization of Religion in Nigeria. Ibadan: IFRA.

Ezeanokwasa, Oseloka. J. 2007. The Islamic Development Bank (IDB) Loan and Secularity of Nigeria. Nigeria World. October 9. Available online: http://nigeriaworld.com/articles/2007/oct/091.html (accessed on 10 April 2016).

Falola, Toyin. 1998. Violence in Nigeria: The Crisis of Religious Politics and Secular Ideologies. New York: University of Rochester Press.

Faseke, Babajimi O. 2013. The Battle for Hearts and Minds: Religious Peacebuilding as an Alternative Solution to Boko Haram Terrorist Threat. IUP Journal of International Relations 7: 41-58.

Gambari, Ibrahim. A. 1989. Theory and Reality of Foreign Policy Making: Nigeria after the Second Republic. Atlantic Highlands: Humanities Press International Inc.

Haynes, Jeffrey. 2012. Religious Transnational Actors and Soft Power. Surrey: Ashgate.

Hunwick, John. 1996. Sub-Saharan Africa and the Wider World of Islam: Historical and Contemporary Perspectives. Journal of Religion in Africa 26: 230-57. [CrossRef]

Jama'atu Nasir Islam. 1986. The Position of Muslims with regard to OIC. Press Statement. New Nigerian, March 20. Jolaoso, Olujimi. 1986. OIC: A give-and-take approach. Guardian (Nigeria), February 28, 9.

Kaura, Tijani. 2008. Nigeria still a member of the OIC. Thisday, April 14, 13.

Kokole, Omari. H. 1984. The Islamic Factor in African-Arab Relations. Third World Quarterly 6: 687-702. [CrossRef]

Kukah, Mathew. H. 1993. Religion, Politics and Power in Northern Nigeria. Ibadan: Spectrum Books.

Kukah, Mathew, and Toyin Falola. 1995. Religious Militancy and Self-assertion: Islam and Politics in Nigeria. Aldershot: Ashgate.

Lawal, Yahaya. 2018. (Director of African Affairs in the Political Department of the OIC, 2005-2018). Interview with Babajimi Faseke. Abuja, Nigeria, July 20.

Oded, Arye. 1987. The promotion of Islamic activities by Arab countries in Africa-contemporary trends. Asian and African Studies 21: 281-304.

Ofeimun, Odia. 1989. In praise of the OIC. Guardian (Nigeria), March 8, 9.

Ohadike, Don. 1992. Muslim-Christian conflict and political instability in Nigeria. In Islam and National Integration in Africa. Edited by John Hunwick. Evanston: Northwestern University Press, pp. 101-25. 
Okojie, Olubunmi. 1986. Nigeria Should Withdraw from the OIC. Newswatch, February 24.

Olukoshi, Adebayo. 1990. The Long Road to Fez: An Examination of Nigeria's Decision to become a full Member of the Organisation of Islamic Conference. In The Structure and Processes of Foreign Policy Making and Implementation in Nigeria, 1960-1990. Edited by Gabriel Olusanya and Rafiu A. Akindele. Lagos and Ibadan: NIIA and Vantage Publishers International Limited, pp. 488-504.

Paden, John. 1986. Ahmadu Bello, Sardauna of Sokoto: Values and Leadership in Nigeria. London: Hodder \& Stoughton. Piscatori, James. 2000. Religious transnationalism and global order, with particular consideration of Islam. In Religion and Global Order. Edited by John Esposito and Michael Watson. Cardiff: University of Wales Press, pp. 66-99.

Shagaya, John. 1986. OIC consultative Committee Report. Guardian (Nigeria), March 22, 1.

Shinkaiye, John. 2018. (Chief of Staff to the Chairperson of the African Union, 2010-2017). Interview with Babajimi Faseke. Abuja, Nigeria, July 20.

Stremlau, John. 1977. The International Politics of the Nigerian Civil War 1967-1970. Princeton: Princeton University Press. Tukur, Sani. 2016. Islamic Development Bank Agrees to Help Develop Northern Nigeria. Premium Times Magazine. January 31. Available online: http://www.premiumtimesng.com/news/more-news/197768islamic-development-bankagrees-help-develop-northern-nigeria.html (accessed on 22 March 2016).

(c) 2019 by the author. Licensee MDPI, Basel, Switzerland. This article is an open access article distributed under the terms and conditions of the Creative Commons Attribution (CC BY) license (http:/ / creativecommons.org/licenses/by/4.0/). 